\title{
Unsustainable Capitalism: Marx and Polanyi Contributions
}

\section{Simone GHEZZI ${ }^{1}$, Enzo MINGIONE ${ }^{2}$}

\author{
ARTICLE INFO \\ Article History: \\ Date Submitted: 20.04.2018 \\ Date Accepted: 24.01.2019 \\ JEL Classification: \\ $\mathrm{B} 1$, \\ B24, \\ B31 \\ Keywords: \\ Marx, \\ Polanyi, \\ Capitalism, \\ Unsustainable \\ Capitalism, \\ Capitalist Accumulation, \\ Double Movement
}

ABSTRACT

The article explores the importance of Marx's and Polanyi's theoretical thinking to understand the dynamics of capitalism. Both Marx and Polanyi assume the importance of agency in shaping contemporary societies by means of different logics and methodologies. Marx is explicit in his theoretical frame but leaves various problems open to further theoretical investigation with reference to the impact of class agency in the historical transformation of capitalism. Polanyi is relatively more attentive to the roles of agencies in building historically different and changing forms of re-embedding processes.

Marx's views on the capitalist economy may bolster the argument that contemporary global capitalism is an unsustainable and tension-ridden form of development. His contribution is, in some way, complementary to an interpretation of the current perspectives of capitalism inspired by Polanyi's idea of the "double movement".

\footnotetext{
${ }^{1}$ Assoc. Prof. Università di Milano-Bicocca, Department of Anthropology.

2 Prof. Università di Milano-Bicocca, Department of Sociology.
} 
Marx's understanding of capitalist industrial society is exceptionally important because, at the same time, it explains capitalism and contributes to alter the dynamic of capitalism itself through its political impact. Both the scientific and the political contributions of Marxian thought remain crucial today in societies that have radically changed since the nineteen-century, the time in which European societies went through their first industrial revolution that constituted the socio-economic reality nurturing Marx's analysis. However, the vast and complex work of Marx has to be revisited with a critical eye particularly attentive to the current transformation and dynamism of global capitalism. In this article, we will briefly discuss how Marx's views on the capitalist economy may bolster the argument that contemporary global capitalism is an unsustainable and tension-ridden form of development. His contribution is, in some way, complementary to an interpretation of the current perspectives of capitalism inspired by Polanyi's idea of the "double movement" (Mingione, 2018). This concept is expounded in The Great Transformation (1944) where Polanyi states that

"while on the one hand markets spread all over the face of the globe and the amount of goods involved grew to unbelievable dimensions, on the other hand a network of measures and policies was integrated into powerful institutions designed to check the action of the market relative to labor, land, and money" (2001 [1944], p.79).

Block, by contrast, seems to warn us on this point, as he claims that "Polanyi's thesis of the double movement contrasts strongly with both market liberalism and orthodox Marxism in the range of possibilities that are imagined at any particular moment" (Block, in Polanyi 2002 [1944], p.xxix). In fact, we are not so much concerned to debate on the possible alternative outcomes, as to point out some interesting analogies in their analysis of the current dynamics of capitalism. For example, Marx's emphasis on class struggles addresses the importance of the role of action and social movements in the dynamics of the current social transformation. This issue singles out the contradictory dynamics of capitalism and, therefore, a coherence with Polanyi's notion of the "double movement":

We are not the only ones to advocate a "positive association" between Marx and Polanyi. This has convincingly been laid out by economic anthropologist Rhoda Halperin. As she puts it: "The relationship between Polanyi and Marx is complex. In some ways Polanyi's 
work is an interpretation of Marx; in some ways it is an elaboration, or at least a significant departure; in some ways it is a critique!" $(1988$, p.56). One important affinity between them is a common definition of the economy. Polanyi's substantive meaning of the economy that “derives from man's dependence for his living upon nature and his fellows" (1957, p.243), and that "refers to the interchange with his natural and social environment", is very similar to the definition found in Marx: "all production is appropriation of nature on the part of an individual within and through a specific form of society (Marx 1973, p.86). Moreover, without adopting a similar terminology, Marx and Polanyi share the notion of disembedded economy. Marx's discussion of "the fetishism of the commodity" (1976, pp.163-177) introduces the idea that social relations among people - whether capitalists, workers or consumers - are in fact expressed as relations between things. Money in particular "conceals $[\ldots]$ the social relations between the individual workers, by making those relations appear as relations between material objects" (168-169). These observations suggest that the market is able to impose its own exploitative and "artificial" rules with inevitable distortions in society. In a similar vein Polanyi argues that "a market economy must comprise all elements of industry, including labor, land, and money. [...] But labor and land are no other than natural surroundings in which it exists. To include them in the market mechanism means to subordinate the substance of society itself to the laws of the market" (Polanyi 1944: 71). Out of this process of subordination of social relations to the market under capitalism, Polanyi formulates his abstract conception of a "disembedded" economy (Cangiani 2010, p.329). In Marxian terms, such a process can indeed be equated to the notion of commodification of social relations. Commodification and disembeddedness, thus, constitute the common conceptual ground upon which opposing movements emerge: Marx looks at class struggles and at the action of workers' solidarity, whereas Polanyi, almost a century later, looks at the "countermeasures" out of the double movement, in which the working class movement is only one the possible manifestation of counter-movement.

Marx's contribution is vast and varied. Many lines of interpretation are controversial and the adaptation of his analytical tools to radically transformed current societies is an engaging task on any ground. We will limit our discussion to two arguments: the dynamic of capitalism and the role of agency. By combining Marx and Polanyi through this discussion, we aim at providing some insights regarding the paradigm of unsustainable development. We will conclude discussing briefly the usefulness of this paradigm vis a vis the orthodox visions of 
formalized economies, centred on static equilibrium, sustainable growth, competitivity and productivity.

Marx's interpretation of the dynamic of capitalism is centred on the theorization of two different forms of accumulation - primitive and capitalist - as drafted, at least in their main lines, in the last part (part eight, chapters 26-33) of the first Volume of the Capital. Both forms of accumulation are necessary in order to explain the genesis of capitalism and its characteristics, and present complementary features: forcible dispossession and impositions for the former, market competition for the latter ${ }^{3}$. Commodification, competition, and profit - the main elements of the capitalist mode of production and of the capitalist accumulation dynamic - cannot come about if the violent disruption of pre-capitalist socio-political orders does not occur $^{4}$. This process is constituted by primitive accumulation and, on this issue we shall devote great attention because it is crucial for the understanding of contemporary capitalism as well. Moreover, it is one of the main points of convergence between the two different approaches of Marx and Polanyi. With the notable exception of Eric Wolf (1982), Immanuel Wallerstein (1974), and the world-system theory literature, Marxist scholars have largely ignored the persistent importance of primitive accumulation and the fact that it is not only a preliminary temporary step for the establishment of the mode of production, but also, and mainly, a long lasting historical process necessary for the expansion and transformation of capitalism.

Contrary to the ideas of most classical economists and theorists, Marx is aware that the industrial transformation cannot take place just because commodities are more convenient to produce and consume. Preindustrial peasant economies and communities cannot be dismantled

\footnotetext{
3 "We have seen how money is transformed into capital; how surplus-value is made through capital, and how more capital is made from surplus-value. But the accumulation of capital presupposes surplus-value; surplusvalue presupposes capitalist production; capitalist production presupposes the availability of considerable masses of capital and labour-power in the hands of commodity producers. The whole movement, therefore, seems to turn around in a never-ending circle, which we can only get out of by assuming a primitive accumulation [...] which precedes capitalist accumulation; an accumulation which is not the result of the capitalist mode of production but its point of departure." (Marx, 1976, p.873).

4 "The starting-point of the development that gave rise both to the wage-labourer and to the capitalist was the enslavement of the worker. The advance made consisted in a change in the form of this servitude, in the transformation of feudal exploitation into capitalist exploitation. [...] In the history of primitive accumulation, all revolutions are epoch-making that act as levers for the capitalist class in the course of its formation; but this is true above all for those moments when great masses of men are suddenly and forcibly torn from their means of subsistence, and hurled onto the labour market as free, unprotected and rightless proletarians.". (Marx, 1976, p.875-876).
} 
by monetary competition because they are strongly established on their traditional values and are economically self-sufficient. The fact that the pre-industrial communities are often oppressive, unjust and unequal may lead to instability and rebellion but not to industrialization and commodification. Only a violent disruption of preindustrial non-commodified orders makes economic self-sufficiency no longer viable and leads, in some cases and at specific historical conditions, to industrialization, commodification and capitalist revolution. The two main examples of primitive accumulation given by Marx - enclosures and colonialism - are important in order to understand his line of thinking on the matter.

Enclosures, that is the abolition by law and force of agricultural community rights to cultivate lands which was sponsored by the landlords against peasant communities, had been happening in western Europe, mainly but not only in England, for many centuries, starting from the $12^{\text {th }}$ century and becoming increasingly more frequent in the $17^{\text {th }}$ and $18^{\text {th }}$ centuries. Often enclosures were only a matter of power and domination for landowners that wanted to recuperate more land for hunting games and, in any case, not related directly to commodification and industrialization. However, the disruption of the traditional ways of survival in agricultural communities had two unwanted effects that have been important in favouring the capitalist industrial revolution. A large number of peasants no longer able to survive in the countryside had to migrate to the cities where they survived as vagrants, thieves, servants, and so on; later they would become a good source for the new working class in factories. At the same time, the villagers still practicing a peasant economy had to find ways of producing resources for survival in order to compensate the ones lost by the prohibition to cultivate the enclosed lands. They thus intensified agricultural and textile work. Increasing the intensity of land cultivation contributed to the beginning of the agriculture industrialization. On the other hand, village textile production traded by merchants contributed substantially to the early development of the manufacturing revolution, particularly in England.

Colonization and the commercial oppression of the global south show a similar story of violent disruption of traditional community life not directly linked to industrialization. At the base of the colonial expansion, there is a question of power and accumulation of wealth by the dominating nations and their commercial and military aristocracies. The massacres and enslavements of local populations are not immediately in relation to industrialization and capital 
accumulation even if, as well noticed by Arrighi (1994; 2009) and Wolf (1982), the capitalist industrial revolution could not have taken place without the contribution of the colonial empires $^{5}$. In the case of colonialism, the disruption of traditional communities generated real enslavements or forced work in mines or large plantations producing raw materials that later became essential for the western industrial revolution. The disrupted rural communities became no longer self-sufficient for survival and resulted in famine or poor monetary consumption. A good example of the importance that colonialism assumed in the process of capitalist development is the role of the Indian empire in the English industrial revolution. A mass of Indian peasants was forced into cotton plantations in order to fuel the British textile industries and, at the same time, the Indian population became consumers of British textile commodities after the forced closure of their village textile craft production.

The primitive accumulation impact of colonization and later an unequal commercial exchange continued for a long time as conditions changed that Marx could not foresee and we will argue that they are still operative now on a large scale. In the last decades, the disruption of local and tribal communities has fuelled the gigantic growth of cities inhabited by an extremely poor population in slums and shantytowns, a new enormous reserve army. Although Marx is often ambiguous on the modernizing role of colonialism, it is difficult to deny that new severe forms of oppression without any perspective of emancipation accompany the violent disruption of the traditional way of life of the populations of the global south. However, we shall come back to this point when comparing Marx's view of the dynamic of capitalism as formed by the two mechanisms of accumulation with Polanyi's theory of the double movement.

The example of colonialism contributes to an extensive interpretation of primitive accumulation. Violent political disruption of traditional habits is always necessary to reinforce, enlarge, and transform capitalism beyond the limits of overproduction and under consumption of capital accumulation. Capitalism has not collapsed and has gone through four industrial

\footnotetext{
${ }^{5}$ As Eric Wolf has noted, "primitive accumulation required not only the seizure of resources but also their concentration, organization, and allocation. [...] Their pursuit favored the emergence of overarching organizations that could focus such large-scale expansionist and mercantile efforts, and that could rally the surplus-producing populace to such goals.

The overarching organizations that developed were states characterized by a high degree of concentration of command, whether placed in the hands of a single ruler and his clientele, as in Portugal and Spain, or in a committee of the ruling oligarchy, as in the United Provinces of the Netherlands" (1982, p.109).
} 
revolutions that have dramatically increased productivity, invented new commodities and transformed the organization of production and the modes of life because primitive accumulation has constantly contributed to create new markets and new habits that the capitalist accumulation commodification process could not have done by itself. So the two different logics of primitive and capital accumulation, as historically interlinked in different contradictory forms, are both necessary to understand and explain the dynamic of capitalism and, finally, its unsustainable nature. Let us speak briefly of capital accumulation and its limits and contradictions. Here, in order to better achieve the goal of the article, we will be concise on the question, which has been at the centre of all the Marxist economic debates, and we will skip the controversies on surplus value and exploitation.

The core of capitalist accumulation is market competition, commodification and the capacity to make profits. For Marx the commodity production system is contradictory and unstable, even beyond the question of exploitation of workers, because market competition systematically disconnects the needs of the population from their capacity to buy goods for survival, as established by their monetary income, and from the quality and quantity of goods produced. This systematic mismatch is in part transformed in increasing economic inequalities and impoverishment of people but also in recurrent overproduction crisis where jobs, goods and firms are destroyed. When Polanyi discusses the question of human work in the capitalist labour market as a fictitious commodity that is unsustainable, he is clearly inspired by this reasoning of Marx. The workers are paid according to the value set by market competition that has nothing to do with the resources they need to survive and live in societies where the traditional community support has been destroyed by primitive accumulation according to Marx and by the double movement according to Polanyi. Here we have anticipated a comparative point that we will discuss later on.

The limits and contradictions of capitalist accumulation according to Marx can be synthesized as follows. Accumulation occurs by increasing productivity prompted by the introduction of organizational changes and new machinery, which systematically displace living labour, that is workers. Condemned to unemployment and lower wages workers will face impoverishment and will respond with rebellion. Meanwhile, the increased productivity will turn to overproduction and escalating competition, which will make the rate of profit fall, 
leading eventually to the collapse of the capitalist mode of production. Looking only at the dynamic of capital accumulation the final collapse of capitalism seems due to take place rather soon with accelerations of productivity mobilizing the working class to smash the capitalist order. However, Marx himself is not thinking of the combined impact of primitive and capitalist accumulation. New disruptions of community traditions offer to capitalism new market opportunities in order to compensate overproduction, create a large area of consumerism, concede to the most productive workers of advanced industrial countries higher salaries and welfare support, and open new production sectors for the realization of high profits. These disruptions of community life and culture are still taking place nowadays, as violent and repressive as ever. They have an extractive and predatory logic, dismantle the community life of autochthonous populations and impose expulsions, expropriations, invasions in favour of multinational business and "modernization" (Sassen, 2014).

Primitive accumulation maintains its political and violent character but it is now immediately an integrated part of the capitalist dynamics. At these conditions, capitalism has the chance to renovate itself a number of times and to become globalized. It becomes then important to reconsider the Marxist question of the force of the class struggle that constitutes the agency of the end of capitalism. The industrial working class of the advanced capitalist countries is shrinking, often divided and privileged, the new large working class of emerging economies is far from expressing an anticapitalistic mobilization, and the resistance of local populations to predatory penetration shows serious limits of weakness and fragmentation. However, before returning in the conclusions to the question of agency we would like to come back to the comparison between Marx and Polanyi on the unsustainability of capitalist development.

We have already noticed in passing that the theory of primitive accumulation contains the same logic of the first part (disembedding) of the double movement, that is the disruption of traditional community habits and livelihood. However, Polanyi thinks that disruption is a product of commodification (in Marxian terms we would say that it happens within capitalist accumulation itself) and not necessarily by a violent political intervention not necessarily linked to the economic process. We have also noticed that both Marx and Polanyi share the conviction that the commodification of work is unsustainable because it systematically fails to match the 
livelihood needs of the workers paid according to their competitive market value. Both Marx and Polanyi are aware, contrary to the orthodox economists, including Keynes (1930) for instance $^{6}$, that within a market competition system the gains of productivity are not redistributed in favour of workers. This means for workers' loss of jobs, technological unemployment, increasing fragmentation and instability, while financial capital is controlling a larger and larger share of income and wealth (Picketty, 2013). In order to go a little further into the comparison we have to recall briefly the main lines of the double movement.

Polanyi (1944, 1957, and 1977) insists on the tensions between the logic of market exchange and the ones of organized societies. At the core of the market dynamic, the supply/demand confrontation becomes effective in so far it fixes competitive prices. This function though is incompatible with social bonds and traditional community cultures. Consequently, the diffusion of the market economy is producing a disembedding movement destroying social links. However, in order for a society to exist as such, a simultaneous reembedding movement takes place establishing new social bonds more compatible with the functioning of the market. Disembedding offers new opportunities to work and consume that are emancipating, freeing individuals from traditional, often oppressive, social conditions (rural communities and villages, clans, tribes, patriarchal families, etc.). At the same time, the disembedding movement opens a deficit of social protection and obliges individuals to reconstruct social bonds able to support their own livelihood at the new conditions imposed by market diffusion. The double movement constitutes the dynamic of modern societies as exposed to commodification within different historical and socio-cultural conditions. It is a traumatic process not only because the destruction and reconstruction of social bonds affect the livelihood of millions with a lot of sufferance but also because the commodification of the three fictitious commodities - work, nature and finance - is unsustainable. We have already mentioned the question of work and its strong analogy with Marx. Polanyi is also a pioneer in posing the ecological question. The market logic of immediate profits and advantages destroys nature

\footnotetext{
${ }^{6}$ Keynes is optimistic on the social impact of the great increase of productivity because he assumes that it will be redistributed to the whole population that will work only a fifteen-hour week shift and have a lot of free time to dedicate to other activities. He is aware of the question of the distribution of wealth but, contrary to Marx and Polanyi, he assumes that it will be over without traumatic conflicts. "All kinds of social customs and economic practices, affecting the distribution of wealth and of economic rewards and penalties, which we now maintain at all costs, however distasteful and unjust they may be in themselves, because they are tremendously useful in promoting accumulation of capital, we shall be free, at last, to discard." (1930, p.364)
} 
without considering the question of its reconstitution and leading to great ecological disasters. And finally, he is a pioneer on the forecast of the financialization disasters pointing to the perspective of the autonomous growth of the financial market oppressing the material economy and increasing the economic inequalities.

Polanyi is not only worried by the devastation produced by the disembedding part of the movement, but also by the fact that re-embedding, in order to combine market competition and social protection and inclusion, can take the form of repressive and authoritarian regimes. The success of fascism and Nazism in-between the two world wars is for him a sign of the great fragility of market societies. As well noticed by Piore (2008) ${ }^{7}$, Polanyi, differently from Marx and other authors, does not forecast the end of the double movement (and capitalism) but is aware that the tensions between market and society pose a very serious problem. Competitive individualization in social isolation, without social protection and social rights is an unsustainable situation. However, Polanyi is relatively ambiguous on the question of agency compared to other authors, and to Marx in particular. It is not always clear how social actors (more or less organized in different ways) put the ri-embedding part of the double movement in motion ${ }^{8}$. This point leads us to discuss briefly the contribution of Nancy Fraser and conclude on the question of agencies in contemporary societies.

Nancy Fraser (2011) argues that Polanyi disregards the importance of the organized struggles for emancipation and suggests that the double movement should become a triple movement including the motion of emancipation struggles and movements. ${ }^{9}$ However, this

\footnotetext{
${ }^{7}$ Michael Piore (2008) in a discussion of the social theories of capitalism and the double movement signals how Polanyi's interpretation is open ended and less teleological with respect to other visions of modernity. However, as the idea of the double movement begins at a precise historical moment when the diffusion of market occasions and the process of industrialization started to subvert the traditional ways of life of the peasant societies we can also assume that the process will arrive at an end when the commodification subversion can no longer take place. ${ }^{8}$ In The Great Transformation Polanyi gives many historical examples of the impact of marketization in XIX century Britain in terms of confrontations and political conflicts where opposing social forces are clearly identified. However, he does not develop a vision on how the re-embedding motion takes place in terms of more or less organized forms of action in favour of the building of new social bonds and forms of social solidarity. 9 'I propose to broaden Polanyi's problematic to encompass a third project that crosscuts his central conflict between marketization and social protection. This third project, which I call emancipation, aims to overcome forms of domination rooted in both economy and society. [...] struggles for emancipation constitute the missing third that mediates every conflict between marketization and social protection. The effect of introducing this missing third will be to transform the double movement into a triple movement." (Fraser 2011: 140)
} 
revision is problematic. The double movement is in fact simultaneously constituted by two discerning parts: the disembedding motion activated by the competitive market and the reembedding motion activated by the necessity to create new social bonds in order to keep societies alive. The immediate and casually linked character of the two parts of the double movement is a key feature of the concept.

However, the double movement puts in motion the promotion of individual identities and agencies that give life to the emancipation movements opposing traditional and new forms of oppression. The double movement originates the processes of democratisation, liberation and emancipation but these are not an instantaneous third part of the double movement itself. Emancipation movements vary across times and contexts, and oppose both the traditional forms of oppression (for instance patriarchy both in the reciprocity forms of organisation - in families and communities - and in market and state organisations) and the new forms of oppression fuelled by capitalist development (like pollution and environmental destruction or increasing bureaucratic and political burdens).

The emancipation content of commodification happens in two different forms: the disembedding from the oppression of traditional communities and the promotion of individual identities favouring the development of emancipation movements and organizations. The idea of emancipation is an important theoretical tool as it explains the potentials and force of commodification beyond violence, imposition or individual economic advantages. The progressive weakening of the emancipation impulse may be an argument in favour of the end of capitalism and of the double movement. As argued by Fraser (2014), Polanyi himself has not noticed this feature. "Associating change exclusively with decay and decline, it overlooks the possibility, noted by Marx, that marketization can generate emancipatory effects, by dissolving modes of domination external to the market and creating the basis for new, more inclusive and egalitarian solidarities.” (p. 547)

Both Marx and Polanyi assume the importance of agency in shaping contemporary societies but within different logics and methodologies. Marx is explicit in his theoretical frame but leaves various problems open with reference to the impact of class agency in the historical transformation of capitalism. Polanyi, as anticipated, is theoretically ambiguous but relatively 
more attentive to the roles of agencies in building historically different and changing forms of re-embedding processes.

Beyond the general idea that history is a product of class struggles, Marx assumes that the confrontation between capitalists and the new industrial working class is the core of the political dynamic of capitalism. His idea is that the capitalist mode of production is crisis ridden, unsustainable and contradictory but it does not collapse by itself. The mobilization and struggle of the organized working class is necessary to terminate capitalism and establish a new socioeconomic order (mode of production). Then how this process happens in the process of capitalist historical transformation is not at all clear. It is difficult to imagine that the working class becomes at the same time increasingly conscious and well organized, on the one hand, and desperate and impoverished, on the other. We know historically that the working class of the western industrialized countries has become increasingly mobilized and organized, as predicted by Marx, but this has not only prevented impoverishment, but it has allowed to acquire social and political rights. The large masses hit by proletarianization in the global south have become impoverished and desperate but only in few cases (China, Vietnam, for example) they have arrived to a political socialist revolution. And yet, these cases are also those to put under critical examination the anticapitalistic content of these revolutions.

Marx has not really taken a clear position on the intermediate and progressive role of working class mobilization in changing capitalist societies before the revolution. He did not live enough to see the positive effects of trade unions and labour reforms, nor the distortions that bureaucratization and elitism produce on the working class political organizations (as predicted by Max Weber). On a different ground, Marx's historical political analysis of the regime crisis in the XIX century is insightful and original ${ }^{10}$. He is attentive to the divisions of the bourgeoisie, to the importance of political organizations and ideological messages, to the building of historical regimes that are different from the previous ones and transform capitalism. We cannot go any further into this discussion, but it may still be interesting now to learn from Marx historical political works how to understand the political scenario of changing political regimes and class confrontations.

\footnotetext{
${ }^{10}$ See, for example, The Eighteenth Brumaire of Louis Bonaparte (1852) and The Civil War in France (1871).
} 
As we have anticipated, in Polanyi's terms agency is behind the re-embeddedness process. In addition, Fraser points to the importance of the organized mobilization of emancipation and democratization movements. As capitalism and the double movement are unsustainable, the burning issue becomes how agency can contrast this fact and, at the same time, build an alternative order. We can question both in Marx's and in Polanyi's theories the exhaustion of the emancipation influence of capitalism. Are perhaps the newly developing countries facing the same risk in the present historical conjunction ${ }^{11}$ ? It is difficult to answer to this question also because historical change has become very fast and unpredictable. The social movements or the class mobilizations in Marx terms do not appear strong and stable enough to build a new order. It is difficult now to think of the class struggle as imagined by Marx in the XIX century because of the individualization and fragmentation that capitalism has produced and because of the global diversity. However, the unsustainability of capitalism as learned from Marx and Polanyi is a good starting point to criticize the oppression of inequalities and domination, and to understand the direction of unpredictable change fashioned by human agencies.

The paradigm of unsustainable capitalist development inspired by Marx and Polanyi is an important tool in order to focus on the real tensions, contradictions and sufferance of the present dynamic of capitalism and to elude the orthodox illusions of growth, equilibrium and competitiveness. The question of the end of capitalism or the double movement of market societies has just begun to be addressed and discussed (Wallerstein and others, 2013; Streeck, 2016; Streeck and others, 2016; Harvey, 2014). The discussion raises the question of human agencies that create a socio-political order alternative to the capitalist one. In a recent book, Streeck (2016, p. 59) takes a pessimist position on the possibility to activate and mobilise movements able to regenerate social cohesion and a new, socially inclusive society:

'The demise of capitalism ... is unlikely to follow anyone's blueprint. As the decay progresses, it is bound to provoke political protests and manifold attempts at collective

\footnotetext{
${ }^{11}$ The capitalist process is now, at the time, generating increasing inequalities in the life conditions of citizens of industrialized countries while dramatically changing the life chances of billions of citizens in the global south. It is difficult to say how this controversial process will go on. As noticed by Wallerstein et al. (2013, p.186): "Only after 1945 were the former peasants and working classes of the West and Soviet bloc factored into social security and prosperity by their national states. In total, this amounted to several hundred millions people. But are there now resources, let alone political will, to factor in several billion people in the global South?"
} 
intervention. But for a long time, these are likely to remain of the Luddite sort: local, dispersed, uncoordinated, "primitive" - adding to the disorder while unable to create a new order, at best unintentionally helping it to come about.'

As we have seen, at the present conditions of social fragmentation of movement and social classes, the position of Streeck sounds reasonable. However, we have now well learned that human agencies are largely unpredictable and we cannot know for sure where fragmented and local resilience and rebellion will lead for the good or for the bad.

\section{Bibliografical references}

Andreotti A., Benassi D., Kazepov Y., eds., 2018, Western Capitalism in Transition. Global Processes Local Challenges, Manchester: Manchester University Press.

Arrighi, G. 1994, The Long Twentieth Century: Money, Power and the Origins of Our Times. London: Verso.

Arrighi, G. 2009, Postscript to the second edition of The Long Twentieth Century: Money, Power and the Origins of Our Times London: Verso.

Block, F. (2001) Introduction, in Polanyi (2001) [1944] The Great Transformation, Boston: Bacon Press, pp.xix-xxxviii.

Cangiani, M (2003) The Forgotten Institution, International Review of Sociology, 13 (2), pp.327-341.

Fraser, N., 2011, Marketization, Social Protection, Emancipation: Towards a Neo-Polanyan Conception of the Capitalist Crisis, in Calhoun, C. \& Derluguian, G. (eds) Business as Usual: The Roots of the Global Financial Meltdown. New York: NYU Press, p.138159.

Fraser, N, 2014, Can society be commodities all the way down? Post-Polanyian reflections on capitalist crisis, Economy and Society, Volume 43 Number 4: 541-558. 
Halperin, R. (1988) Economies across Cultures Towards a Comparative Science of the Economy, New York: Palgrave Macmillan

Harvey, D. (2014). The Seventeen Contradictions and the End of Capitalism. London: Profile Books.

Keynes, J. M., 1930, Economic Possibilities for our Grandchildren, in John Maynard Keynes, Essays in Persuasion, New York: W.W: Norton \& Co., pp. 358-373.

Marx, K. (1973) [1939] Grundrisse. Introduction to the Critique of Political Economy. New York: Random House.

Marx, K. (1976), Capital, Vol.1, Harmondsworth: Penguin.

Mingione E. 2018, The double movement and the perspectives of contemporary capitalism, in Andreotti, Benassi, Kazepov, op.cit, 291-306.

Piketty, T., 2013, Le capital au XXIe siècle, Paris : Seuil. (English version): 2014, Capital in the Twenty-first Century, Harvard: Belknap.

Piore, M., 2008, Second Thoughts: on Economics, Sociology, Neoliberalism, Polanyi's Double Movement and Intellectual Vacuums, Boston: MIT Working Papers.

Polanyi, K. 2001 [1944], The great transformation: The political and economic origins of our times. Boston: Beacon Press.

Polanyi, K. 1957 The economy as instituted process. In K. Polanyi, C.M. Arensberg and H.W. Pearson (eds), Trade and market in the early empires: Economies in history and theory, New York: Free Press. 243-70.

Polanyi, K. 1977 The livelihood of man, ed. H. Pearson. New York: Academic Press.

Sassen, S. (2014) Expulsions. Brutality and Complexity in the Global Economy, Cambridge Mass. and London: Harvard University Press. 
Stiglitz, J., 2012, The Price of Inequality, London: Allen Lane.

Streeck, W. (2016), How Will Capitalism End?, London and New York: Verso.

Streeck, W. and others (2016), Discussion Forum. Does Capitalism have a future?, SocioEconomic Review, vol.14, No.1, 163-183.

Wallerstein, I. (1974), The Modern World-System: Capitalist Agriculture and the Origins of the European World-Economy in the Sixteenth Century, New York: Academic Press.

Wallerstein I. and others. (2013) Does Capitalism Have a Future? Oxford: Oxford University Press.

Wolf, E. (1982) Europe and the People Without History, Berkeley and Los Angeles: University of California Press. 